Resisting

history

Religious transcendence

and the invention

of the unconscious

$\sim$

RHODRI HAYWARD

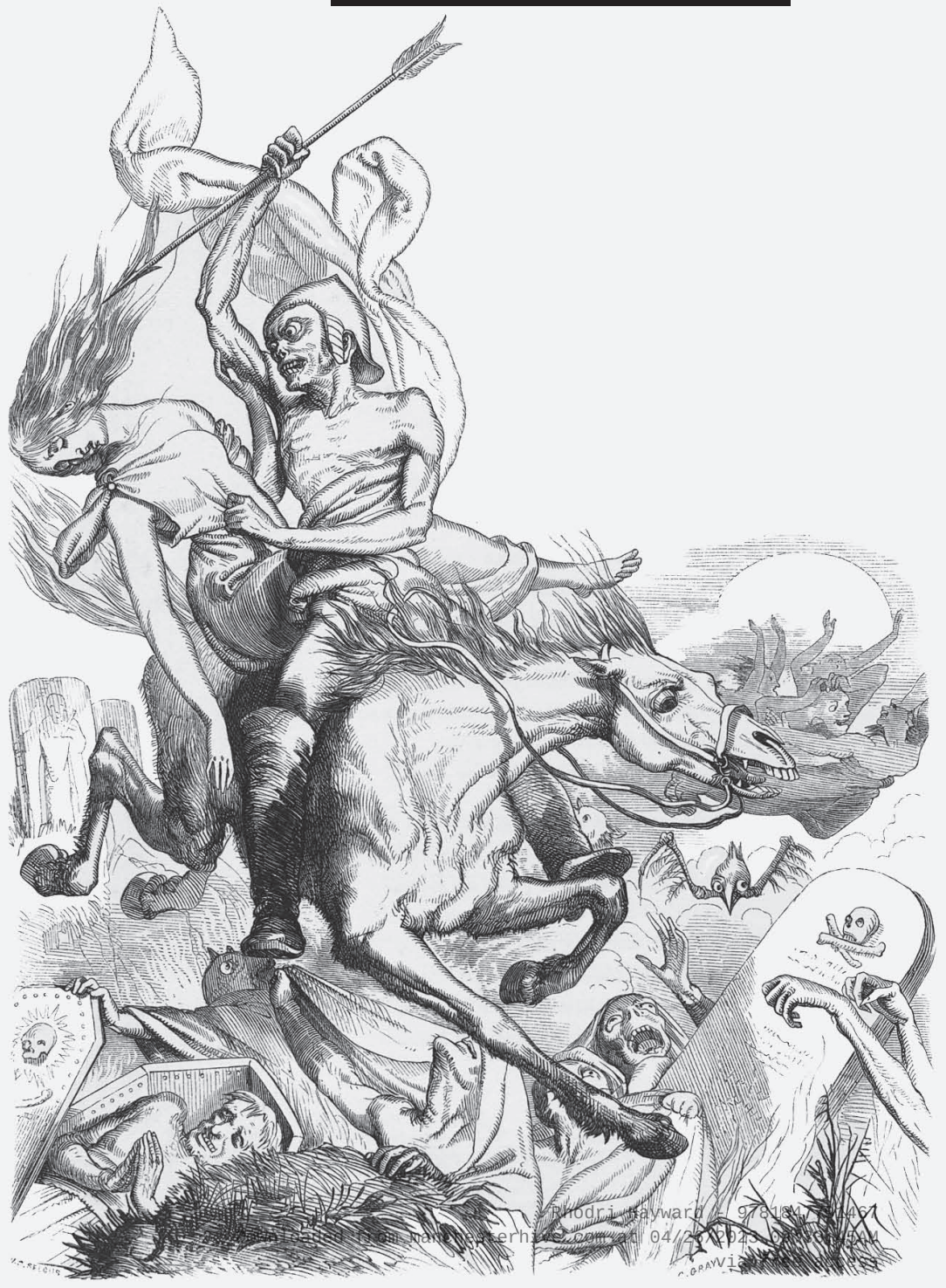




\title{
Resisting history
}

\author{
$\sim$
}

\section{MANCHESTER \\ 1824}

Manchester University Press 


\section{ENCOUNTERS cultural histories}

Series editors:

Roger Cooter

Harriet Ritvo

Carolyn Steedman

Bertrand Taithe

Over the past few decades cultural history has become the discipline of encounters. The issues raised by new 'turnings' - linguistic, pictorial and spatial - through theorists such as Bourdieu, Foucault, Derrida, Deleuze and Spivak have contributed to the emergence of cultural history as a forum for bold and creative exchange. This series places encounters human, intellectual and disciplinary - at the heart of historical thinking. Encounters provides an arena for exploring new and reassembled historical subjects, for stimulating perceptions and reperceptions of the past, and for methodological challenges and innovations. It invites short, innovative and theoretically informed books from all fields of history.

Already published

Benjamin's Arcades: An unGuided tour Peter Buse, Ken Hirschkop, Scott McCracken and Bertrand Taithe

Poison, detection and the Victorian imagination Ian Burney

Plants, patients and the historian Paolo Palladino

Mourning becomes ... : Post/memory, commemoration and the concentration camps of the South African War Liz Stanley

Dust Carolyn Steedman 


\section{Resisting history}

Religious transcendence and the invention of the unconscious

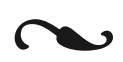

RHODRI HAYWARD

Manchester University Press

Manchester 


\section{Copyright $\odot$ Rhodri Hayward 2007}

The right of Rhodri Hayward to be identified as the author of this work has been asserted by him in accordance with the Copyright, Designs and Patents Act 1988.

Published by Manchester University Press

Altrincham Street, Manchester, M1 7JA, UK

www.manchesteruniversitypress.co.uk

Vancouver, BC, Canada V6T 1Z2

British Library Cataloguing-in-Publication Data is available

Library of Congress Cataloging-in-Publication Data is available

ISBN 9780719095375 paperback

First published by Manchester University Press in hardback 2007

This paperback edition first published 2014

The publisher has no responsibility for the persistence or accuracy of URLs for any external or third-party internet websites referred to in this book, and does not guarantee that any content on such websites is, or will remain, accurate or appropriate. 